\title{
Comércio Exterior
}

\author{
Foreign Trade
}

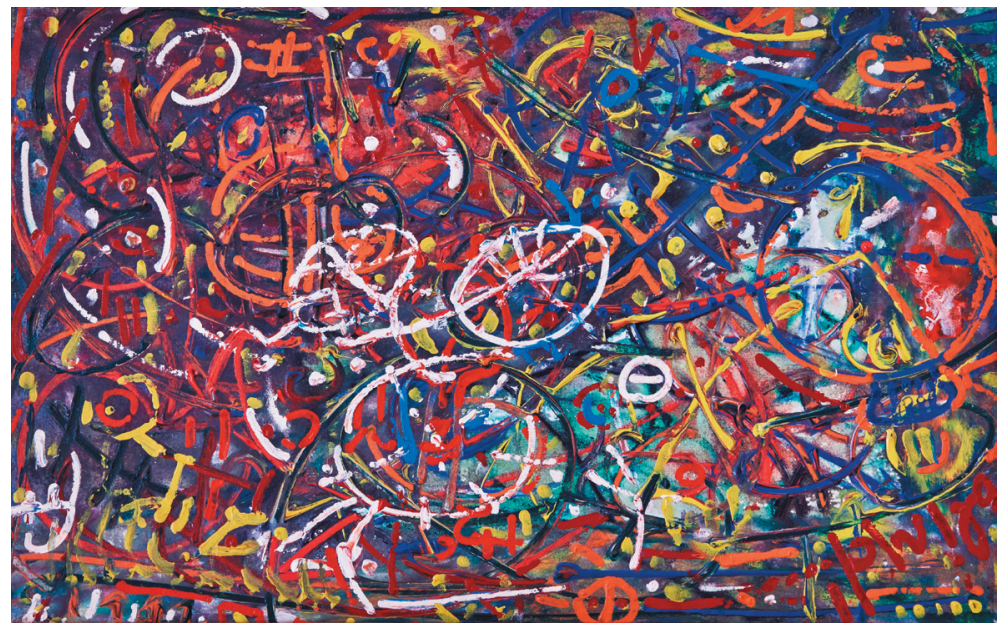

Sem Título/Untitled, 1994 J. Medeiros 



\section{Comércio Exterior}

\section{Foreign Trade}

\section{Fragilidades dos Fluxos Externos do Brasil no Período 2013-2015}

O setor externo brasileiro apresenta extrema relevância para o crescimento do país, contribuindo para o fechamento da Conta de Transações Correntes, na medida em que é um setor dinâmico e afetado pelas crises externas e internas. No período de expansão da economia mundial (2003 a 2007), o Brasil foi beneficiado pelo aumento do saldo comercial e, consequemente, pela recuperação da liquidez internacional. Contudo, a crise de 2008 afetou sobremaneira as contas externas brasileiras, tornando-se um ponto de inflexão na dinâmica do setor externo e, posteriormente, agravando a deterioração das contas externas.

De acordo com o Gráfico 19.1, as exportações brasileiras vêm oscilando ao longo do período analisado (2008 a 2015), devido a fatores externos e internos. Primeiramente, houve uma queda na demanda mundial, ocasionando em uma redução do total exportado. Segundo, após a recuperação da confiança do mercado internacional,

\section{Weaknesses of Brazil's Foreign Flows in the 2013-2015 Period}

The Brazilian foreign sector has great relevance in the country's growth, contributing to the closing of the Current Account Transactions, since it is a dynamic sector and affected by the internal and external crisis. In the expansion period of the world economy (2003 to 2007), Brazil was benefited by the increase of the trade balance and, consequently, by the recovery of the international liquidity. However, the 2008 crisis exerted a great impact on the Brazilian foreign accounts, becoming an inflection point in the dynamics of the foreign sector and, later, worsening the deterioration of the foreign accounts.

According to Graph 19.1, the Brazilian exports oscillated throughout the analyzed period (2008 to 2015) due to external and internal factors. At first, there was a decrease in the world demand, causing a reduction of the total exports. Secondly, after regaining the confidence of the international 
a apreciação do real deslocou as exportações brasileiras, o que resultou que esses dois fatores combinados reforçam a vulnerabilidade externa estrutural do país. No entanto, esse movimento contribuiu para o aumento das importações, reduzindo assim o hiato do saldo comercial, o qual registou saldo deficitário de aproximadamente US\$ 4 bilhões no ano de 2014. Assim, ainda que as exportações tenham crescido durante todo o período, as importações também o fizeram pari passu.

Contudo em 2015, fatores como retração da economia interna e a desvalorização cambial contribuíram para o saldo comercial positivo de aproximadamente US\$ 19 bilhões. Esse cenário foi alcançado pela queda superior das importações (em média 25\%) vis-àvis das exportações (em média 15\%), contribuindo para o saldo positivo.

Segundo Tabela 19.2, entre todas as categorias exportadas aquela que apresentou maior queda entre 2013 e 2015 foram os Produtos Primários com cerca de $22 \%$, seguido de Produtos Manufaturados com decréscimo de aproximadamente $21 \%$ e, por fim, os Produtos Semimanufaturados com perda de $13 \%$ em média do total exportado. Percebe-se que o padrão das exportações brasileiras ainda é intensivo em Produtos Primários, categoria essa que possui participação média de $46 \%$ entre 2013 e 2015, ou seja, em produtos pouco processados e com determinação do preço e demanda no mercado internacional (HIRATUKA E CUNHA, 2011).

Este padrão de especialização torna o país vulnerável às crises externas, na medida em que não é capaz de estabelecer market, the appreciation of the real displaced the Brazilian exports. The result of these two factors combined was the reinforcement of the external structural vulnerability of the country. However, this movement contributed to the increase of imports, narrowing down the gap of the trade balance, which registered a deficit of approximately US\$4 billion in 2014. Thus, even though the exports increased along the whole period, so did the imports hand in hand.

Nevertheless, some factors such as the contraction of the domestic economy and currency depreciation contributed to the positive trade balance of nearly US\$19 billion in 2015. This scenario was depicted by the higher drop of the imports (on average $25 \%$ ) in comparison with the exports (on average 15\%), contributing to the positive balance.

According to Table 19.2, the highest fall among all export categories between 2013 and 2015 was Primary Products, with nearly $22 \%$, followed by Manufactured Products with a decrease of around $21 \%$ and, at last, the Semi-Manufactured Products, with a $13 \%$ loss, on average, of the total exports. It can be seen that the Brazilian export pattern is still focused on Primary Products - a category which had an average contribution of $46 \%$ between 2013 and 2015 -, i.e., on lightly-processed products and with pricing and demand determined by the foreign market (HIRATUKA E CUNHA, 2011).

This pattern of specialization makes the country vulnerable to external crises because it is not able to 
o preço dos seus principais produtos exportados. Os produtos manufaturados que compõem cerca de $38 \%$ em média da pauta exportadora brasileira ainda apresentam baixa participação e concentração com relação ao destino das exportações, na medida em que seus principais mercados são ALADI, MERCOSUL E NAFTA (CUNHA, 2014).

Um dos principais fatores que contribuiu para a queda das exportações de Produtos Primários foi a retração da economia chinesa, uma vez que esse era um dos principais mercados consumidores de commodities brasileiras. No entanto, a principal motivação para a retração foi o preço das commodities que tem apresentado um declínio desde 2014 (IPEADATA, 2016). O mercado internacional de produtos manufaturados brasileiros também não consegue se expandir na medida em que seu principal destino é a Argentina, país este que também passa por um período de crise econômica.

Enquanto as exportações são intensivas em produtos com baixo valor agregado e poder de negociação internacional, as importações se caracterizam pelo alto valor adicionado. A categoria de Matérias-primas e Bens Intermediários possui participação de $45 \%$ em média na pauta importadora, seguida pela categoria de Bens de Capital com $22 \%$ de participação e Combustíveis e Lubrificantes e Bens de Consumo ambos com média de $17 \%$ no período analisado. Este perfil do setor externo torna o Brasil vulnerável, na medida em que não apresenta proteção contra crises externas e internas dada sua dependência estrutural de commodities e/ou produtos pouco processados establish the price of its main exporting goods. The manufactured products that comprise nearly $38 \%$ on average of the export list of Brazil still record low contribution and concentration in relation to the destination of exports, since the main markets are LAIA, MERCOSUR and NAFTA (CUNHA, 2014).

One of the main factors that contributed to the decrease of the exports of Primary Products was the contraction of the Chinese economy, for it was one of the major consuming markets of the Brazilian commodities. However, the main motivation for the contraction was the price of the commodities that has been decreasing since 2014 (IPEADATA, 2016). Besides, the international market of the Brazilian manufactured products is not able to grow because their main destination is Argentina, a country that is also undergoing a period of economic crisis.

While the exports are intensive in products with low value added and international trading power, the imports are characterized by high value added. The category Raw Material and Intermediate Goods contributes with $45 \%$ on average to the import list, followed by the category Capital Goods, with $22 \%$ of participation and Fuel and Lubricants and Consumer Goods, both with 17\% on average in the analyzed period. Such profile of the foreign sector makes Brazil vulnerable, since there is no protection against external or internal crises given its structural dependence on commodities and/or lightly processed products coupled 
aliada a uma indústria interna débil e dependente.

A queda das importações, portanto, tem sido influenciada pela retração da atividade e investimento em capital produtivo. De acordo com a Tabela 19.3, a importações de Bens de Capital tiveram uma redução de aproximadamente $40 \%$ no período de 2013 a 2015, passando de mais de US\$ 51 milhões para apenas US\$ 37 milhões. Bem como a categoria de matérias primas e bens intermediários teve uma redução de cerca $31 \%$, o que indica uma redução da atividade industrial.

A categoria Bens de Consumo sofreu uma queda de $32 \%$ no período analisado, sendo parte significativa atribuída à redução de Bens de Consumo Duráveis (queda de 49\%), movimento esse influenciado pela queda da demanda interna devido ao aumento do custo de vida mensurado pela inflação de 10,67\% (IPEADATA, 2016) e pela taxa de desemprego que ficou em torno de 8,5\% (IBGE, 2016). No entanto, a maior redução do período foi atribuída à categoria de Combustíveis e Lubrificantes que reduziu-se em $44 \%$ desde 2014 e quase $90 \%$ desde 2013. Essa queda é atribuída, além da redução da atividade industrial, também à depreciação cambial que tornou esses produtos mais caros para o Brasil.

Apesar do saldo comercial positivo, o Saldo de Transações Correntes ainda é negativo, conforme Tabela 19.1. Esse saldo negativo nas Transações Correntes é de natureza estrutural devido ao déficit na Conta de Serviços. Este déficit está associado à saída with a fragile and dependent domestic industry.

The drop of the imports, therefore, has been influenced by the contraction of the activity and of the investment in productive capital. According to Table 19.3 , the import of capital goods had a reduction of nearly $40 \%$ in the period between 2013 and 2015, going from more than US\$51 million to just US\$37 million. The category of raw material and intermediate goods, as well, had a reduction of around $31 \%$, which indicates a decrease in the industrial activity.

The Consumer Goods category fell by $32 \%$ over the analyzed period, with a significant part attributable to the reduction of Durable Consumer Goods (down 49\%), a movement that was influenced by the fall in the domestic demand due to the increased cost of living measured by the $10.67 \%$ inflation (IPEADATA, 2016) and by the unemployment rate, which was approximately $8.5 \%$ (IBGE, 2016). However, the further reduction of the period was due to the category of Fuels and Lubricants, which has fallen by $44 \%$ since 2014 and almost $90 \%$ since 2013. Besides the reduction of the industrial activity, this decrease is also attributed to the exchange rate depreciation that made these products more expensive for Brazil.

Despite the positive trade balance, the Current Account Balance is still negative, as shown in Table 19.1. This negative balance in the Current Account is of structural nature, due to the deficit in the Services Account. This deficit is associated with the exit of Profits 
de Lucros e Dividendos das Empresas Multinacionais instaladas no país, bem como também despesas com viagens internacionais, embora tenha havido uma queda de $23 \%$ com relação ao ano de 2014. No entanto, segundo Pereira (2014), esse déficit histórico da Conta de Serviços apesar de se reduzir com a desvalorização cambial, ainda depende mais de aumentos contínuos de produtividade do que os efeitos cambiais. Isto porque a produtividade brasileira é muito baixa comparada com outros países como a própria China e mesmo assim não tem apresentado melhoria na sua posição (PEREIRA, 2014).

O déficit em Transações Correntes, juntamente com o déficit na Conta Financeira e Investimento Direto Estrangeiro, mantêm o Balanço de Pagamentos negativo nos últimos 3 anos (2013 a 2015). Isso implica uma necessidade de poupança externa elevada, o que resulta em políticas econômicas restritivas da atividade econômica como, por exemplo, desvalorização da taxa de cambio, redução do nível das atividades econômicas via aumento da taxa de juros, restrições às importações e controle de remessa de capitais ao exterior, dentre outras. Embora haja déficit no Balanço de Pagamento pode-se perceber que as Reservas Internacionais têm crescido desde 2001 a 2015, conforme Gráfico 19.2. Isto porque as reservas internacionais, que tem a função de manter a credibilidade internacional e evitar a vulnerabilidade, tem se elevado fortemente por meio do endividamento público, tornando o país ainda mais fragilizado frente a crises internacionais.

Portanto, as políticas econômicas deveriam caminhar no sentido de maior apoio ao and Dividends from Multinational Enterprises established in the country, and also with expenses with international trips, although there has been a fall of $23 \%$ in relation to 2014 . However, according to Pereira (2014), this historical deficit of the Services Account, despite being reduced with the currency devaluation, still depends more on the continued productivity increases than on the currency effects. It happens because the Brazilian productivity is very low when compared with other countries' (like China) and has not yet shown improvement (PEREIRA, 2014).

The deficit in Current Accounts along with the deficit in the Financial Account and Foreign Direct Investment kept the Balance of Payments negative in the last 3 years (2013-2015). This implies a need for high foreign savings, which results in economic policies that restrict the economic activities, as, for example, the depreciation of the exchange rate, the reduction of the level of economic activities by the increased interest rate, import restrictions and control of the remittance of capital abroad, among others. Although there is a deficit in the Balance of Payments, it is notable that the international reserves grew from 2001 to 2015, as shown in Graph 19.2. That is because the international reserves, which play the role of maintaining international credibility and avoiding vulnerability, have strongly increased by means of public debt, making the country even more exposed to the international crises. 
setor externo com o fortalecimento da indústria interna e, por consequência, redução da vulnerabilidade externa. Este cenário somente seria possível com uma mudança do padrão de especialização rumo a produtos mais intensivos em tecnologia e diversificação dos parceiros comerciais. sector by strengthening the domestic industry and, consequently, reducing external vulnerability. This could only be possible with a shift in the specialization pattern towards more technology-intensive products and with the diversification of trading partners.

\section{Referências}

CUNHA, S. F. (2014) Especialização Comercial Intraproduto: o desempenho exportador brasileiro e chinês em variedades verticalmente diferenciadas. Universidade Estadual de Campinas, Instituto de Economia: Campinas. Tese de Doutoramento.

HIRATUKA, C.; CUNHA, S. F. (2011) Qualidade e Diferenciação Das Exportações Brasileiras E Chinesas: Evolução Recente No Mercado Mundial E Na Aladi. Instituto de Pesquisa em Economia Aplicada - IPEA. Texto para discussão, 1622.

INSTITUTO BRASILEIRO DE GEOGRAFIA E ESTATISTICA (2016). Disponível em:<https://www.ibge.gov.br/home/ estatistica/indicadores/precos/inpc_ipca/defaultinpc.shtm>. Acesso em 4 jul. 2016.

INSTITUTO DE PESQUISA ECONÔMICA APLICADA (2016) - Ipeadata. Dados macroeconômicos e regionais. Disponível em: <http://www.ipeadata.gov.br>. Acesso em 4 jul. 2016.

PEREIRA, L. V. (2014) Déficits, uma questão estrutural. Revista Conjuntura Econômica, vol. 68, no. 03 , março.

\section{References}

CUNHA, S. F. (2014) Especialização Comercial Intraproduto: o desempenho exportador brasileiro e chinês em variedades verticalmente diferenciadas. State University of Campinas, Institute of Economics: Campinas. PhD Thesis.

HIRATUKA, C.; CUNHA, S. F. (2011) Qualidade e Diferenciação Das Exportações Brasileiras E Chinesas: Evolução Recente No Mercado Mundial E Na Aladi. Institute for Applied Economic Research - IPEA. Discussion paper, 1622.

INSTITUTO BRASILEIRO DE GEOGRAFIA E ESTATISTICA (2016). Disponível em/Available from:<http://www.ibge. gov.br/home/estatistica/indicadores/precos/inpc_ipca/defaultinpc.shtm>. Acesso em/Cited:Jul. 2016.

INSTITUTO DE PESQUISA ECONÔMICA APLICADA (2016) - Ipeadata. Dados macroeconômicos e regionais. Disponível em/Available from: <http://www.ipeadata.gov.br>. Acesso em/Cited: Jul. 2016.

PEREIRA, L. V. (2014) Déficits, uma questão estrutural. Revista Conjuntura Econômica, vol. 68, no. 03 , March. 


\section{Clésio Lourenço Xavier}

Graduação em Economia pela Universidade

Federal de Uberlândia - UFU

Mestre em Economia - Universidade Estadual

de Campinas - UNICAMP

Doutor em Economia - Instituto de Economia

UNICAMP

Professor do Instituto de Economia da

Universidade Federal de Uberlândia IEUFU

e Pesquisador Bolsista de Produtividade do

CNPq.
Bachelor in Economics from the Federal

University of Uberlândia - UFU

Master in Economics from the State University of

Campinas - UNICAMP

PhD in Economics from the Institute of Economics of UNICAMP

Professor of the Institute of Economics of the

Federal University of Uberlândia - IEUFU and

Fellow Researcher on Productivity at the CNPq.

\section{Maria Inês Cunha Miranda}

Graduação em Economia pela Universidade

Federal de Uberlândia - UFU

Mestre em Economia - Universidade Federal de

Uberlândia - UFU

Pesquisadora do Núcleo de Economia Aplicada do IEUFU e Doutoranda do Programa de PósGraduação em Economia.
Bachelor in Economics from the Federal University of Uberlândia - UFU

Master in Economics from the Federal University of Uberlândia - UFU

Attending a PhD Program in Economics at the Federal University of Uberlândia - UFU

Researcher of the Applied Economics Center of IEUFU and attending a PhD Program in Economics.

Translated by: Gisele Flores Caldas Manhães 
Tabela 19.1 - Balanço de pagamentos - 2013-2015

Table 19.1 - Balance of payments - 2013-2015

\begin{tabular}{|c|c|c|c|}
\hline \multirow{2}{*}{$\begin{array}{l}\text { Especificação/ } \\
\text { Item }\end{array}$} & \multicolumn{3}{|c|}{$\begin{array}{l}\text { Valor } 1000000 \text { US\$/ } \\
\text { Value } 1,000,000 \text { US\$ }\end{array}$} \\
\hline & 2013 & 2014 & 2015 \\
\hline $\begin{array}{l}\text { Balança comercial/ } \\
\text { Trade balance }\end{array}$ & 319 & $(-) 6629$ & 17670 \\
\hline $\begin{array}{l}\text { Exportações/ } \\
\text { Exports }\end{array}$ & 241507 & 224098 & 190092 \\
\hline $\begin{array}{l}\text { Importações/ } \\
\text { Imports }\end{array}$ & 241189 & 230727 & 172422 \\
\hline $\begin{array}{l}\text { Serviços/ } \\
\text { Services }\end{array}$ & (-) 46232 & (-) 48107 & (-) 36978 \\
\hline $\begin{array}{l}\text { Renda Primária/ } \\
\text { Primary income }\end{array}$ & (-) 32538 & (-) 52170 & (-) 42357 \\
\hline $\begin{array}{l}\text { Renda secundária/ } \\
\text { Secondary income }\end{array}$ & 3683 & 2725 & 2724 \\
\hline $\begin{array}{l}\text { Transações correntes/ } \\
\text { Current account }\end{array}$ & (-) 74769 & (-) 104181 & (-) 58942 \\
\hline $\begin{array}{l}\text { Conta capital/ } \\
\text { Capital account }\end{array}$ & 322 & 231 & 440 \\
\hline $\begin{array}{l}\text { Conta financeira/ } \\
\text { Financial account }\end{array}$ & (-) 72336 & (-) 100599 & (-) 56692 \\
\hline $\begin{array}{l}\text { Investimento direto (líquido)/ } \\
\text { Direct investment (net) }\end{array}$ & (-) 54240 & (-) 70855 & (-) 61576 \\
\hline $\begin{array}{l}\text { Erros e omissões/ } \\
\text { Errors and omissions }\end{array}$ & 2110 & 3351 & 1810 \\
\hline
\end{tabular}

Fonte/Source: Séries temporais. Tabelas especiais. Setor externo. In: Banco Central do Brasil. SGS: sistema gerenciador de séries temporais. Brasília, DF, [2016]. Disponível em/Available from: <http://www4.bcb.gov.br/pec/series/port/aviso.asp>. Acesso em: jan. 2016/Cited: Jan. 2016. 
Tabela 19.2 - Exportação - 2013-2015

Table 19.2 - Exports - 2013-2015

\begin{tabular}{|c|c|c|c|}
\hline \multirow{2}{*}{$\begin{array}{l}\text { Especificação/ } \\
\text { Item }\end{array}$} & \multicolumn{3}{|c|}{$\begin{array}{l}\text { Valor } 1000000 \text { US\$ Fob/ } \\
\text { Value } 1,000,000 \text { US\$ Fob }\end{array}$} \\
\hline & 2013 & 2014 & 2015 \\
\hline $\begin{array}{l}\text { Total/ } \\
\text { Total }\end{array}$ & 242034 & 225101 & 191134 \\
\hline $\begin{array}{l}\text { Produtos básicos/ } \\
\text { Primary products }\end{array}$ & 113023 & 109556 & 87188 \\
\hline $\begin{array}{l}\text { Produtos semimanufaturados/ } \\
\text { Semi-manufactured products }\end{array}$ & 30526 & 29065 & 26463 \\
\hline $\begin{array}{l}\text { Produtos manufaturados/ } \\
\text { Manufactured products }\end{array}$ & 92945 & 80211 & 72791 \\
\hline $\begin{array}{l}\text { Operações especiais/ } \\
\text { Special operations }\end{array}$ & 5540 & 6268 & 4692 \\
\hline
\end{tabular}

Fonte/Source: Séries temporais. Tabelas especiais. Setor externo. In: Banco Central do Brasil. SGS: sistema gerenciador de séries temporais. Brasília, DF, [2015]. Disponível em/Available from: <http://www4. bcb.gov.br/pec/series/port/aviso.asp>. Acesso em: jan. 2016/Cited: Jan. 2016.

Tabela 19.3 - Importação - 2013-2015

Table 19.3 - Imports - 2013-2015

\begin{tabular}{|c|c|c|c|}
\hline \multirow{2}{*}{$\begin{array}{l}\text { Especificação/ } \\
\text { Item }\end{array}$} & \multicolumn{3}{|c|}{$\begin{array}{l}\text { Valor } 1000000 \text { US\$ Fob/ } \\
\text { Value } 1,000,000 \text { US\$ Fob }\end{array}$} \\
\hline & 2013 & 2014 & 2015 \\
\hline $\begin{array}{l}\text { Total/ } \\
\text { Total }\end{array}$ & 239748 & 229145 & 171461 \\
\hline $\begin{array}{l}\text { Bens de capital/ } \\
\text { Capital goods }\end{array}$ & 51662 & 47769 & 37662 \\
\hline $\begin{array}{l}\text { Bens de consumo/ } \\
\text { Consumer goods }\end{array}$ & 40966 & 38832 & 30842 \\
\hline $\begin{array}{l}\text { Duráveis/ } \\
\text { Durable }\end{array}$ & 22229 & 20273 & 14862 \\
\hline $\begin{array}{l}\text { Não duráveis/ } \\
\text { Non-durable }\end{array}$ & 18737 & 18560 & 15980 \\
\hline $\begin{array}{l}\text { Matérias-primas e bens intermediários/ } \\
\text { Raw materials and intermediate goods }\end{array}$ & 106503 & 102999 & 81200 \\
\hline $\begin{array}{l}\text { Combustíveis e lubrificantes/ } \\
\text { Fuels and lubricants }\end{array}$ & 40616 & 39545 & 21757 \\
\hline
\end{tabular}

Fonte/Source: Séries temporais.Tabelas especiais. Setor externo. In: Banco Central do Brasil. SGS: sistema gerenciador de séries temporais. Brasília, DF, [2015]. Disponível emVAvailable from: <http://www4. bcb.gov.br/pec/series/port/aviso.asp>. Acesso em: jan. 2016/Cited: Jan. 2016. 


\section{Gráfico 19.1 - Comércio exterior - 2008-2015 \\ Graph 19.1 - Foreign trade - 2008-2015}

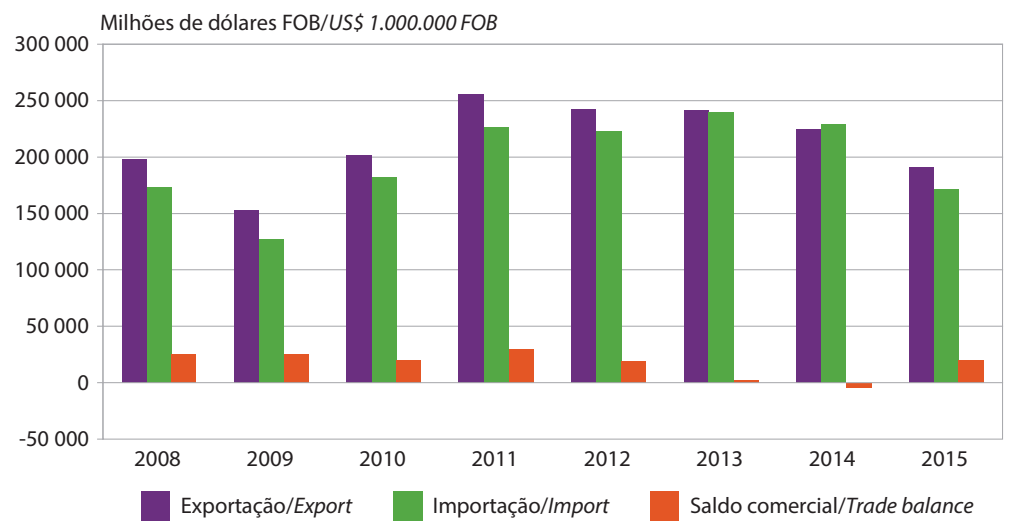

Fonte/Source: Brasil. Secretaria de Comércio Exterior. AliceWeb: sistema de análise das informações de comércio exterior. Brasília, DF: Secex, 2015. Disponível em/Available from: <http://aliceweb.mdic.gov.br/>. Acesso em: jan. 2016/Cited: Jan. 2016.

\section{Gráfico 19.2 - Reservas internacionais - 2001-2015}

Graph 19.2 - International reserves - 2001-2015

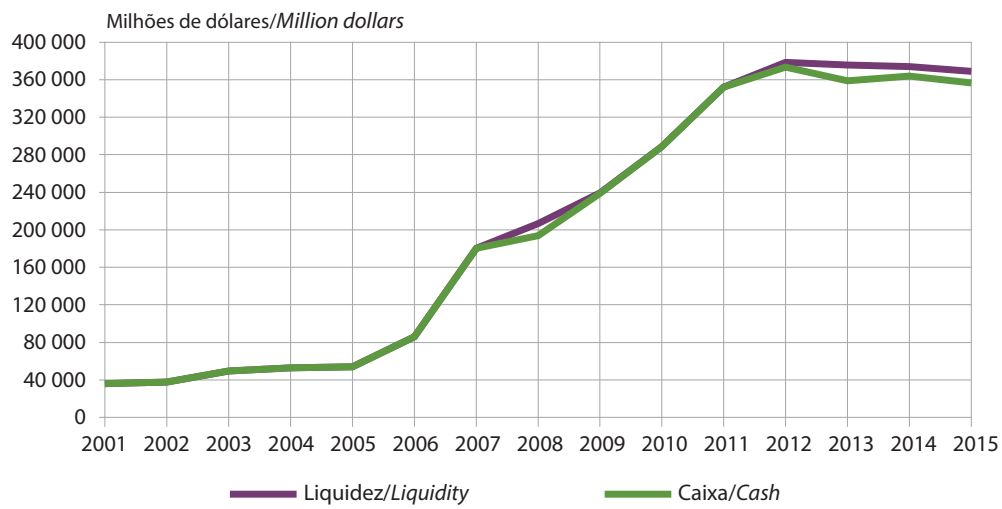

Fonte/Source: Séries temporais. Tabelas especiais. Setor externo. In: Banco Central do Brasil. SGS: sistema gerenciador de séries temporais. Brasília, DF, [2015]. Disponível em/Available from: <http://www4.bcb. gov.br/pec/series/port/aviso.asp>. Acesso em: jan. 2015/Cited: Jan. 2015. 